\title{
Borda Application Of Selection Planning Scheduling Method In Dock Engineering Consultants In Central Sulawesi Province Indonesia
}

\author{
Siti Fatimah ${ }^{(1)}$, Ahmad Laongko ${ }^{(2)}$, Muzakir Tombolotutu ${ }^{(3)}$ \\ Tadulako University \\ ${ }^{1,2,3}$ School of Management, Faculty of Economics and Business \\ Central Sulawesi Province, GPO BOX 94118, Indonesia
}

siti_fatimahj@yahoo.co.id,ahmadlaongko@yahoo.co.id,muzakir.tombolotutu@gmail.com

\begin{abstract}
Purpose : The aim of this paper to find out the planning scheduling method that used in dock engineering consultants as a project supervisor dock.

Design/Methodology/Approach: This research use qualitative approach to find the most preferred method by engineering consultants, this research was explorative that test and find out the most preferred method.

Result: This research showed that dock engineering consultants in Palu City, Central Sulawesi most preferred curve-s method than method such as CPM, PERT, PDM, and Bar Chart.

Practical Implication: This research can help further research to determine differences and similarities the project planning scheduling method and being basic for The New Dock Engineering Consultans.

Originality/Value: This research looking for the most preferred method with limited respondents dock engineering consultans in Palu City, Central Sulawesi.
\end{abstract}

Keyword: CPM, PERT, PDM, S-Curve, Bar Chart, and Free Flat

\section{Introduction}

Indonesia state are known with 1001 islands that rich in various species of fish and famous maritime states including island of Sulawesi. Indonesia is an archipelago based on the position of latitude and longitude lines are in between $6^{\circ}$ Luke $11^{\circ}$ latitude and $95^{\circ}$ BT $-141^{\circ}$ BT. Sulawesi or also known as Celebes is an island located in the sea area in this location resulted in the presence of several species of plants and animals of Sulawesi island. Lots and breadth of the waters of Indonesia, many ports in Indonesia.

Period and change in the mobility of people to create change in the circulation flow the movement of city. As occurs in other port cities of Indonesia, its also true and occurs did exist in Central Sulawesi. Port requires for a dock as a means to pull logistics ship the language or dismissal of logistics ships dock that contains various kinds of fish from domestic and abroad.

This research include how to plan manufacture of dock. Because the planning of project activities is an very important issue because it is the basis for the planning of project activities that are implemented. It can be completed with the optimal time. In the planning stages of the project, it is necessary to estimate the duration of the project

For making the dock requires estimate the duration of the project. The duration of the project that has stated in scheduling must be completed on time. It duration of the project can determine effective or not a dock project. By Sulaeman and Fatlina (2006) project scheduling include activities scheduling resources (labour, material, and fund), and estimate needs resources that needed for complete the activities of the current project started until the project was completed. Project scheduling must be supported by a skilled workforce in the field, experts in the field of dock Construction. In addition, it takes appropriate working methods and skills of the workforce. Project activities require a budget in scheduling as well as in the execution of dock projects, the implementation of projects that require raw materials or dock materials to be qualified in order to make the dock function goes well

\section{Literature Review \\ 2.1 Theory of Project}

In Meredith and Mantel (2006) argued that, "The project is complex enough that the subtasks require careful coordination and control in terms of timing, precedence, cost, and performance." H. Kernzer (cited by Soeharto, 1999) stated that, view of management insight, that project management is planning, organizing, directing, and controlling the resources of the company to achieve shortterm goals. Doing scheduling management needs careful and meticulous calculations to be more efficient and effective in project implementation. There are several methods commonly used to overcome the problem of scheduling the project, the method including the Critical Path Method (CPM), Precedence Diagram Method (PDM), technical bar chart, the $\mathrm{S}$ curve, and PERT (Project Evaluation and Review Technique).

\subsection{CPM Theory}

In Heizer and Render (cited by Eka, 2010), CPM makes the assumption that the time activity is uncertain, until only takes one time for each activity factor. In CPM used way of "deterministic", is wear a point estimate. CPM uses 
one type of time for the estimated time of completion of each activity. CPM is generally used with any form of projects, including construction, product development, engineering and plant maintenance.

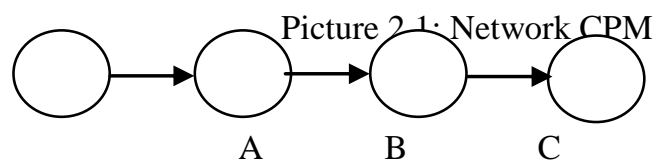

CPM can be used if activities are carried out with a definite time. In CPM method (Critical Path Method) as known with the existence of a critical path that path has circuit components of the total number of events with the longest time. Critical Path Method (CPM) is described as an activity on arrow (activity on arrow - AOA). In AOA activities depicted as arrows connecting two circles represent two events / occurrences, so in CPM there is a dummy which is apparent activity. Imaginary activity is activity without requiring the time, expense or facilities (Emani, et al: 2012). CPM is used to schedule and control the activity that has been done. The time and cost of each element of activity has been known by the evaluators as well as engineering consultants.

\subsection{PERT Theory}

Technique of Project Evaluation and Review Technique (PERT) is a method that aims to reduce the delay, or interruption of production, as well as coordinating the various parts of a work thoroughly and accelerate project completion. This technique produces a controlled and orderly work, because the schedule and budget of the work has already been determined in advance before implemented.

In Heizer and Render (cited Eka, 2010), in PERT used distribution opportunities based on 3 time estimate for every events, among others optimistic time, pessimist time, and realistic time. Levin dan Kirkpatrick (1982) explained that optimistic time is estimate time that has a very small probability to be achieved, possibility occur only once than 100 , pessimist time is an estimate of the time that others who have a very small chance to be realized, the possibility also only once in 100 , while the realistic time or most likely time is the time that is based on the mind estimator. Estimated time optimistic usually expressed by letter a realistic time by the letter $\mathrm{m}$, and pessimistic time stated by the letter $b$.

\subsection{Precedence Diagram Method (PDM)}

Precedence Diagram Method (PDM) is work network that included in activity on node classification (AON). In AON classification, activity can be carried out even if the predecessor activity has not been completed. Activities written in the box and circle and an arrow just explaining dependency relationships between activities.

\section{Picture 2.2: Network PDM}

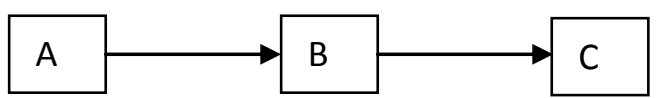

Excess PDAM with Diagram of Arrow is not needed fictitious activities or Dammy so that the manufacturing network being simpler and relation overlapping that differences can make without adding activities amount. Activities in PDM represented by the symbol are easily identified.

\subsection{S-Curve}

S-Curve is a graph the relationship between the time of project implementation with the accumulated value of the progress of the project from start to finish the project. Scurve is common for project proponents. Generally projects using S-Curve in the planning and monitoring of project implementation schedule, both public and private. The Scurve is easy to be composed of two graphs are graphs and charts which is a plan that is realization. The indicator is the only one that is used by the perpetrators of the current project on observations on projects undertaken in Indonesia.

In the s-curve has a weight of project implementation activities. Thus the $\mathrm{S}$ curve can describe the progress of the volume of work completed throughout the course of the project or work in a part of the project. By comparing these curves with a similar curve which is based on planning, it will be seen clearly in the event of irregularities.

According Husen (repository. widyatama.ac.id) To make the S-curve, the amount of the cumulative percentage of the weight of each activity in a period between project duration is plotted against the vertical axis so that when the results are connected by lines to form such Form $\mathrm{S}$ curve occurs because the volume activity at the beginning is usually still a little bit, then in the mid-rise in quantities large enough, then at the end of the project back to shrink the volume of activity.

\subsection{Theory Bar Chart}

Bar chart is a set list of activities that are arranged in a vertical column direction, and time scale are arranged in columns horizontal direction. When the start and end of an activity can be seen clearly while the duration of the activities described by the length of a bar chart

Picture 2.3: Bar Chart

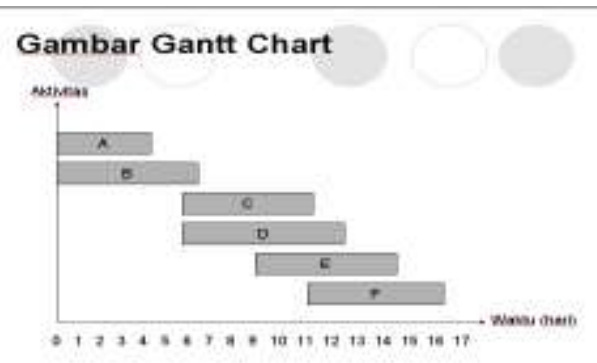

ist of activities to be carried out, arranged in rows under which each activity has the necessary execution time (duration) are shown in the form of a time-scale line (generally thickened lines that resemble the beam). The length of each line / bar represents the length of time required for each activity as well as when to start and end the activity (Suharto, 1999).

\section{Methodology}

By interviewing and receive information data from engineering consultants who have overcome the dock project in Central Sulawesi. This research was supported by the leader of engineering consultants. The research used is a method that is often used to analyze conducting pier project. The existence of an engineering consultant pier in Central 
Sulawesi is very limited because this work requires expertise in analyzing the dock environment also takes skill to predict the weather and climate. To find out what is favorites method of engineering consultants, the researchers using borda method because this method is considered more effective in the process. The research is needed on the opinion of leaders and the engineering consultant firm to required accuracy project planning and implementation method.

Picture 3.1: Research Methodology

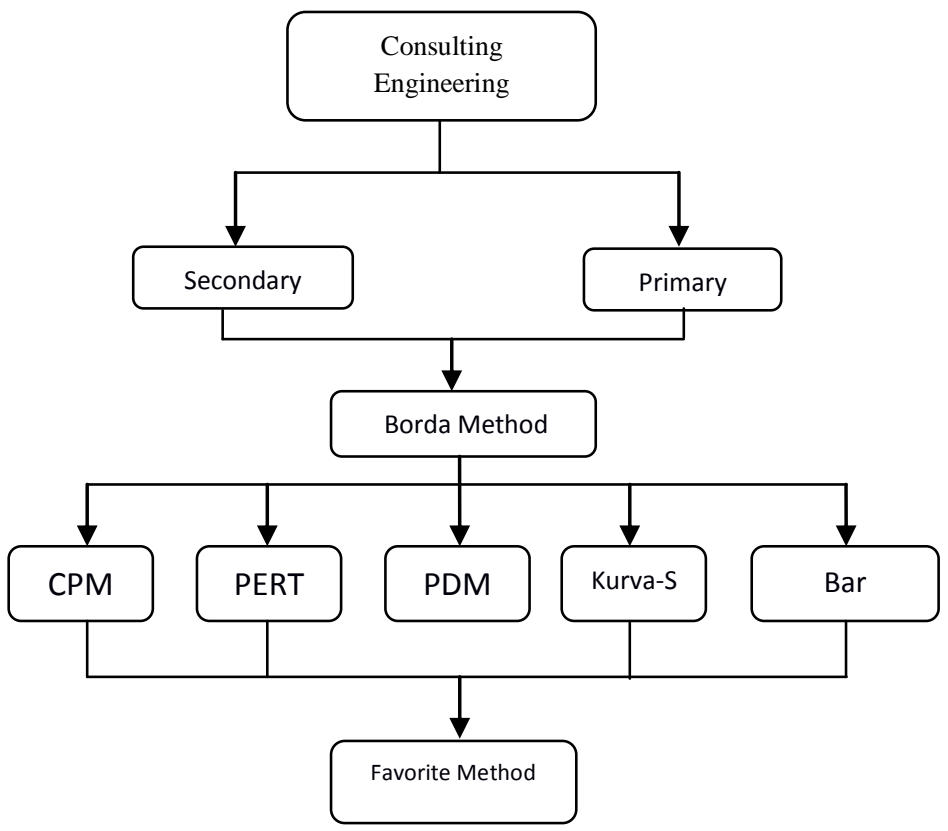

\section{Result and Discussion}

In Palu city, central Sulawesi has a consultant firm. In this research has 3 opinion of engineering consultant, namely:, 1. PT. Total Prakarsa Utama, 2. CV. Krearchindo. 3. CV. Riski Pratama.

The result of the discussions leader for method engineering consulting firm CPM, PERT, PDM, Kurve-s, and Bar Chart in use in the dock engineering consultants of Palu City, Central Sulawesi.

Tabel 4.1 : The results of discussions about Differences And Similarities Project Scheduling Planning Methods.

\begin{tabular}{|c|c|c|c|c|c|}
\hline $\begin{array}{l}\mathrm{N} \\
\mathrm{O}\end{array}$ & CPM & PERT & PDM & $\begin{array}{l}\text { KURVA } \\
-S\end{array}$ & $\begin{array}{l}\text { BAR } \\
\text { CHART }\end{array}$ \\
\hline 1. & $\begin{array}{l}\text { Definite } \\
\text { Time }\end{array}$ & $\begin{array}{l}\text { Time } \\
\text { uncertain }\end{array}$ & $\begin{array}{l}\text { Definite } \\
\text { Time }\end{array}$ & $\begin{array}{l}\text { Definite } \\
\text { Time }\end{array}$ & $\begin{array}{l}\text { Ongoing } \\
\text { Time }\end{array}$ \\
\hline 2. & $\begin{array}{l}\text { Requires } \\
\text { network } \\
\text { aktivities } \\
\text { and } \\
\text { formula } \\
\text { of } \\
\text { method }\end{array}$ & $\begin{array}{l}\text { Requires } \\
\text { the last } \\
\text { time data }\end{array}$ & $\begin{array}{l}\text { Can } \\
\text { undertak } \\
\text { e b } \\
\text { before } \\
\text { events } \\
\text { happen } \\
\text { Requires } \\
\text { a weght }\end{array}$ & $\begin{array}{l}\text { Need to } \\
\text { weght }\end{array}$ & $\begin{array}{l}\text { Requires the } \\
\text { implementati } \\
\text { on of the } \\
\text { activities } \\
\text { directly }\end{array}$ \\
\hline 3. & $\begin{array}{l}\text { Have } 2 \\
\text { time }\end{array}$ & $\begin{array}{l}\text { Have } 3 \\
\text { times }\end{array}$ & $\begin{array}{l}\text { Do not } \\
\text { have } \\
\text { time } \\
\text { graph }\end{array}$ & $\begin{array}{l}\text { Have a } \\
\text { 2nd time }\end{array}$ & $\begin{array}{l}\text { Requires } 1 \\
\text { time }\end{array}$ \\
\hline 4. & $\begin{array}{l}\text { Requires } \\
\text { a timing } \\
\text { diagram } \\
\text { reality } \\
\text { and } \\
\text { planning }\end{array}$ & $\begin{array}{l}\text { Takes } \\
\text { pessimist } \\
\text { ic, The } \\
\text { most } \\
\text { likely } \\
\text { time and } \\
\text { time } \\
\text { optimisti } \\
\text { c }\end{array}$ & $\begin{array}{l}\text { There is } \\
\text { a } \\
\text { forward } \\
\text { calculati } \\
\text { on and } \\
\text { back up }\end{array}$ & $\begin{array}{l}\text { Realizati } \\
\text { on takes } \\
\text { time and } \\
\text { planning }\end{array}$ & $\begin{array}{l}\text { Need time } \\
\text { doing }\end{array}$ \\
\hline 5. & $\begin{array}{l}\text { having a } \\
\text { dummy }\end{array}$ & $\begin{array}{l}\text { having a } \\
\text { dummy }\end{array}$ & $\begin{array}{l}\text { Not } \\
\text { require } \\
\text { dummy }\end{array}$ & $\begin{array}{l}\text { Not } \\
\text { require } \\
\text { dummy }\end{array}$ & $\begin{array}{l}\text { Not require } \\
\text { dummy }\end{array}$ \\
\hline 6. & $\begin{array}{l}\text { There } \\
\text { calculati } \\
\text { on of } \\
\text { free flats }\end{array}$ & $\begin{array}{l}\text { Have a } \\
\text { standard } \\
\text { deviation }\end{array}$ & $\begin{array}{l}\text { Have a } \\
\text { standard } \\
\text { deviatio } \\
\mathrm{n}\end{array}$ & $\begin{array}{l}\text { Have a } \\
\text { cumulati } \\
\text { ve value }\end{array}$ & $\begin{array}{l}\text { There is not } \\
\text { calculation }\end{array}$ \\
\hline 7. & $\begin{array}{l}\text { Circular } \\
\text { shape } \\
\text { their } \\
\text { networks }\end{array}$ & $\begin{array}{l}\text { Box } \\
\text { shape } \\
\text { their } \\
\text { networks }\end{array}$ & $\begin{array}{l}\text { Box } \\
\text { shape } \\
\text { their } \\
\text { networks }\end{array}$ & $\begin{array}{l}\text { No form } \\
\text { of } \\
\text { networks }\end{array}$ & $\begin{array}{l}\text { Arranged in } \\
\text { a column- } \\
\text { shaped } \\
\text { horizontal }\end{array}$ \\
\hline
\end{tabular}

\subsection{Borda Analyisis}

The basic idea in Borda Method is with giving weight on each first rank, second rank, etc. Although not essential in this method, seems just will reasonable if this first place worth more According to Cheng (ejournal.uajy.ac.id, 2014) In Group Decision Support System (GDSS) one problem often encountered is how aggregating the opinions of decision makers to make an appropriate decision. Methods in group decision making, especially related to the Multi Criteria Decision Making (MCDM) will usually experience problems when each decision maker provides individual preference. One of the means (tools) used in the aggregation group is making decisions based on voting. Borda method raised by the inventor Jean Charles de Borda in the 18th century is one of the methods used to determine the best alternative of some alternative chosen. Each alternative choice decision makers will be judged by weight based on the ranking. The weight of the largest is the best alternative choice decision makers. The results of 
discussions with manager engineering consultancy about favorite method:

Tabel 4.2: Determination Ranking In Project Scheduling Method

\begin{tabular}{|l|r|r|r|}
\hline \multirow{2}{*}{ METHOD } & \multicolumn{3}{|c|}{ Name of engineering consultancy } \\
\cline { 2 - 4 } & $\begin{array}{c}\text { CV. } \\
\text { KREAR } \\
\text { CHINDO }\end{array}$ & $\begin{array}{c}\text { PT. TOTAL } \\
\text { PRAKARSA } \\
\text { UTAMA }\end{array}$ & $\begin{array}{c}\text { CV. RISKI } \\
\text { PRATAM } \\
\text { A }\end{array}$ \\
\hline CPM & 3 & 2 & 3 \\
\hline PERT & 5 & 5 & 4 \\
\hline PDM & 4 & 4 & 5 \\
\hline Kurva-S & 1 & 1 & 1 \\
\hline Bar Chart & 2 & 3 & 2 \\
\hline
\end{tabular}

Tabel 4.3: Accumulation Project Scheduling Method Rating

\begin{tabular}{|r|l|r|r|r|r|r|}
\hline \multirow{2}{*}{ NO } & \multirow{2}{*}{ METHOD } & \multicolumn{5}{|c|}{ Rank to- } \\
\cline { 3 - 7 } & & 1 & 2 & 3 & 4 & 5 \\
\hline 1 & CPM & 0 & 1 & 2 & 0 & 0 \\
\hline 2 & PERT & 0 & 0 & 0 & 1 & 2 \\
\hline 3 & PDM & 0 & 0 & 0 & 2 & 1 \\
\hline 4 & Kurva-S & 3 & 0 & 0 & 0 & 0 \\
\hline 5 & Bar Chart & 0 & 2 & 1 & 0 & 0 \\
\hline
\end{tabular}

Tabel 4.4: Determination Ranking Project Scheduling Method

\begin{tabular}{|c|c|c|c|c|c|c|c|}
\hline \multicolumn{6}{|c|}{ Weight } & \multirow{2}{*}{ Whole } & \multirow{2}{*}{ Rank } \\
\hline & 4 & 3 & 2 & 1 & 0 & & \\
\hline CPM & 0 & 3 & 4 & 0 & 0 & 7 & 4 \\
\hline PERT & 0 & 0 & 0 & 4 & 0 & 4 & 5 \\
\hline PDM & 0 & 0 & 0 & 8 & 0 & 8 & 3 \\
\hline Kurva-S & 12 & 0 & 0 & 0 & 0 & 12 & 1 \\
\hline Bar Chart & 0 & 6 & 2 & 0 & 0 & 8 & 2 \\
\hline
\end{tabular}

\section{Conclusion}

Dock is a tool that should be owned by every Indonesian island. Aside from being a transport advice sea lanes currents also serves as a dismissal of goods logistics linking of various Indonesian islands or abroad. Dock required for project scheduling engineering consultancy which helps in monitoring the implementation of the project work dock implementation time information is also connected by engineering contractor.

Borda obtained from the application of that method of curve-s get ranked 1, 2 bar chart rankings, ranking third PDM, ranked 4th CPM and PERT scheduling methods to get the final rating is 5. The results of this study found that the favorite scheduling method on project engineering consultant is a curve due to an easily readable from among stakeholders and stokeholders. In addition, the curve-s do not have a network that is easy and fast in execution and reporting of the implementation of the project work in particular dock. Curve-s weighs so much detail aided by the standard deviation and the accumulation of any percentage of project activitie

\section{Reference}

Agung Muhammad, 2008. Seminar Berkala \& Pelatihan Kompetensi Mahasiswa Laboratorium Ilmu Ekonomi. UNHAS: Makasar

Amani wahyu, helmi \& irawan. 2012. Perbandingan Aplikasi CPM, PDM dan Teknik Bar Chart Kurva-S Pada Optimalisasi Penjadwalan Proyek. Buletin ilmiah math. Stat. dan terapannya (BIMASTER)

Eka Dannyanty, 2010. Optimalisasi Pelaksanaan Proyek Dengan Metode PERT dan CPM: Studi Kasus Twin Tower Building Pasca Sarjana UNDIP. Universitas Diponegoro Semarang.

Levin, Richardi \& Charles. Kirkpatrick.1982. Perencanaan Dan Pengendalian Dengan PERT dan CPM. Balai Aksara

Meredith, Jack R \& Samuel J. Mantel,Jr.2006. Project Management; A Managerial Approach John Wiley \& Sons Inc.

Miru Sulaeman \& Fatlina, 2006. Manajemen Industri. Palu: Universitass Tadulako.

Soeharto, Iman.1999. Manajemen Proyek: Dari Konseptual Sampai Operasional. Jilid 1. Jakarta: Erlangga

http://e-journal.uajy.ac.id/5277/3/2MTF01913.pdf $\underline{\text { (2014 Agust 10) }}$

Widyatama,2014. Manajemen Proyek dan Metode Kurva-S (online). Sumber, http://repository.widyatama.ac.id/xmlui/bit stream/handle/123456789/3731/Bab\%202. pdf?sequence $=7$ (2014 October 13) 